\title{
BENEFICIAL EFFECT OF FLAXSEED AND FLAXSEED OIL BY ADJUSTING OMEGAG:OMEGA3 RATIO ON LIPID METABOLISM IN HIGH CHOLESTEROL DIET FED RATS
}

\author{
By \\ Soheir Fawzy Mohamed \\ Hala Mahmoud Nagi \\ Department of Food Science, \\ Faculty of Agriculture, \\ Cairo University, Giza, Egypt \\ Department of Food Science, \\ Faculty of Agriculture, \\ Cairo University, Giza, Egypt \\ Rasha Medhat Mourad \\ Department of Food Science, \\ Faculty of Agriculture, \\ Cairo University, Giza, Egypt
}

\section{Research Gournal Specific Fducation}

Faculty of Specific Education

SYansoura University

ISSUE NO. 58, APRIL, 2020

مجلة بعوث التربية النوعية - جامعة المنصورة

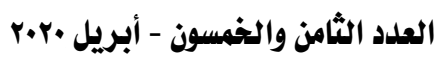




\section{BENEFICIAL EFFECT OF FLAXSEED AND FLAXSEED OIL BY ADJUSTING OMEGAG:OMEGA3 RATIO ON LIPID METABOLISM IN HIGH CHOLESTEROL DIET FED RATS}

Soheir Fawzy Mohamed*

Hala Mahmoud Nagi*

Rasha Medhat Mourad*

\section{Abstract}

Hypercholesterolemia is one of the major risk factors that precipitate coronary heart disease and atherosclerosis. abnormal lipid metabolism is a main cause of dyslipidemia, which is a major risk factor for cardiovascular disease, obesity, cholestasis, and overall mortality. It is well known that diet plays an important role in the control of cholesterol homeostasis. Many studies reported that flaxseed may have protective effect against diseases like cardiovascular diseases CVD, reducing the risk of cancers, reducing the incident and progress of diabetes .High omega-6/omega-3 ratio intake promotes development of many chronic diseases like cardiovascular disease, cancer, inflammatory and autoimoune disease, rheumatoid arthritis, asthma. Accordingly, the purpose of the present study was to investigate the effect of flaxseed and flaxseed oil against high cholesterol diet induced hypercholesterolemia in rats by adjusting $\omega 6: \omega 3$ ratio(2.5:1), Also, to determine whether flaxseed or flaxseed oil when administered to hypercholesterolemic induced-rats beneficial for treatment of hypercholesterolemia complications. Animals(40 rats) were divided randomly into 4 equal groups. G1 fed on basal diet (NC), G2 fed on HFD only(PC) . G3 and G4 fed on HFD with adjust $\omega 6: \omega 3$ ratio(2.5:1) by either flaxseed oil (FSO) or flaxseed( FS) . Blood samples were collected every 3 weeks for lipid parameters monitoring (serum total cholesterol (TC) ,triglycerides (TG) .high density lipoprotein cholesterol (HDL) whereas low density lipoprotein cholesterol (LDL) was calculated. All samples (heart, kidney, spleen, lungs and brain, and liver) of each animal were

* Department of Food Science, Faculty of Agriculture, Cairo University, Giza, Egypt 
weighted. liver and kidney were kept in formalin solution (10\%) for the histopathological investigation

Results showed that $\omega 6: \omega 3$ ratio was 1:3.8 in FS and 1:4.2 in FSO, while such ratio was 10:1 in grease .

The results showed that adjusting $\omega 6: \omega 3$ ratio by FS or FSO led to significant high decrease of plasma cholesterol, triglyceride, LDL and to increase in HDL after 6 weeks . Results also indicated that the balance ratio of $\omega 6: \omega 3$ led to decrease in weight of rats as such ratio is important for health and in the prevention and management of obesity. Histopathology examination of the organs tissue was in parallel with the biochemical results, as liver weight was higher in PC with a marked deterioration in liver tissue while treated groups showed alleviated histopathological alterations. Moreover, kidney tissues in treated group showed apparently normal glomeruli and tubular epithelium, similar to the negative control group. These results suggest that, flaxseed oil may be effective in controlling cholesterolemic status and improving dyslipidemia and has the potential in reducing cardiovascular complications due to hypercholesterolemia.

Key words: Omega6, Omega3, lipid profile, Liver, Hypercholesterolemia ,high cholesterol diet, rats weight , Flaxseed oil; , Flaxseed

\section{Introduction}

Hypercholesterolemia is one of the major risk factors that precipitate coronary heart disease and atherosclerosis.(Hussein et al., 2014)

Ruelet al., (2018): Familial hypercholesterolemia (FH) is an autosomal codominant lipoprotein disorder characterized by elevated lowdensity lipoprotein cholesterol (LDL-C) and high risk of premature atherosclerotic cardiovascular disease. Definitions for FH rely on complex algorithms that are on the basis of levels of total or LDL-C, clinical features, family history, and DNA analysis that are often difficult to obtain.

Molena-Fernandes et al., ( 2010) reported that abnormal lipid metabolism is a main cause of dyslipidemia, which is a major risk factor for cardiovascular disease, obesity, cholestasis, and overall mortality. It is well 
known that diet plays an important role in the control of cholesterol homeostasis Cardiovascular diseases (CVD), mainly including atherosclerosis, hypertension, cardiac hypertrophy, myocardial infarction and heart failure, are the principal cause of death worldwide.( Ali et al.; 2017). Although the development of pharmacotherapies to treat, CVD has contributed to a decline in cardiac mortality.( WHO. 2015 , Moss et al ., 2016 )

Many studies reported that flaxseed may have protective effect against diseases like cardiovascular diseases CVD, reducing the risk of cancers, reducing the incident and progress of diabetes (Mishra,2016 and Ali et al 2017) .

A number of investigations have demonstrated that diet supplemented with flaxseed oil has profound beneficial health effects in various pathologies. Flaxseed is also the richest source of lignans, which have been reported to have antioxidant and hypolipidemic effects (Newairy and Abdou, 2009). Flaxseed in the diet in animal studies has shown inhibit atherogenesis (Prasad, 2005) and protect during hyper-cholesterolemic conditions (Dupasquier et al., 2006).

Omega-6 and omega-3 polyunsaturated fatty acids (PUFAs) are essential fatty acids that must be derived from the diet, cannot be made by humans, and other mammals because of the lack of

endogenous enzymes for omega-3 desaturation . Due to agribusiness and modern agriculture western diets contain excessive levels of omega- 6 PUFAs but very low levels of omega-3 PUFAs,leading to an unhealthy omega-6/omega-3 ratio of 20:1, instead of 1:1 that was during evolution in humans ( Simopoulos , 2016)

High omega-6/omega-3 ratio intake promotes development of many chronic diseases like cardiovascular disease, cancer, inflammatory and autoimoune disease, rheumatoid arthritis, asthma, whereas increased intake of omega-3 fatty acids (reduced omega-6/omega-3 ratio) suppresses the effect ( Gupta et al , 2013) 
Omega-3 PUFAs are primarily found in fish, especially in twait shad, salmon, tuna, and anchovies (Whelan \& Rust, 2006). Another important source of PUFA is flaxseed obtained from Linum usitatissimum plants (Linaceae family), cropped mainly in Argentina, Brazil, Canada, China, India. and Turkey (SAMMOUR, 1999).

Accordingly, the purpose of the present study was to investigate the effect of flaxseed and flaxseed oil against high cholesterol diet induced hypercholesterolemia in rats by adjusting $\omega 6: \omega 3$ ratio(2.5:1), Also, to determine whether flaxseed or flaxseed oil when administered to hypercholesterolemic induced-rats beneficial for treatment of hypercholesterolemia complications.

\section{Materials \& Methods}

\section{Experimental design and diet planning:}

A total number of 40 adults Albino male normal rats, weighing 160$190 \mathrm{~g}$, obtained from Agriculture research institute .

All experiments were carried in the Agriculture research institute. Composition of experimental diets are shown in table(1).

Table (1): Composition of Negative(basal diet) control (NC), positive (high cholesterol)control (PC), Flaxseed oil (FSO) and Flaxseed( FS) diets (g /100g):

\begin{tabular}{|c|c|c|c|c|}
\hline Ingredient & NC & PC & FSO & FS \\
\hline \hline Skim milk & 36.4 & 36.4 & 36.40 & 32.99 \\
\hline Fiber & 1 & 1 & 1 & 1 \\
\hline Starch & 47.60 & 34.6 & 34.63 & 34.55 \\
\hline Salt mixture & 4 & 4 & 4 & 4 \\
\hline Vit. Mixture & 1 & 1 & 1 & 1 \\
\hline Corn oil & 10 & 10 & 7.28 & 7.46 \\
\hline Flaxseed & - & - & - & 6 \\
\hline flaxseed oil & - & - & 2.69 & - \\
\hline Grease & - & 10.00 & 10.00 & 10.00 \\
\hline Cholesterol & - & 2 & 2 & 2 \\
\hline Choline chloride & - & 1 & 1 & 1 \\
\hline
\end{tabular}

NC: Negative control

FSO :Flaxseed Oil group
PC: Positive control

FS :Flaxseed 
Diet in NC group contain $12 \%$ protein , $4 \%$ salt mixture, $1 \%$ vitamin mixture and $10 \%$ fat.

While diets in PC ,flaxseed( FS) and flaxseed oil groups contain $12 \%$ protein , $4 \%$ salt mixture , $1 \%$ vitamin mixture and $20 \%$ fat $(10 \%$ plant oil from either corn oil, flaxseed or flaxseed oil and $10 \%$ grease as animal fat) $2 \%$ cholesterol and $1 \%$ choline chloride.

In all diets, skim milk was served as the main source of protein.

Both salt and vitamin mixtures were prepared according to A.O.A.C(2016).

Diets for both FS and FSO groups were designed with careful consideration, so that $\omega 6$ : $\omega 3$ ratio was balanced in both experimental diets to a ratio of 2.4 and 2.5 :1 respectively by adding $6 \%$ flaxseed side to $7.46 \mathrm{~g}$ corn oil in flaxseed group and $2.69 \%$ flaxseed oil side to $7.28 \mathrm{~g}$ corn oil in flaxseed oil group .

$\omega 6: \omega 3$ ratio in PC group was (29.9:1) as fat source was both corn oil and grease.

\section{Chemical analysis}

Chemical analysis of flaxseed, flaxseed oil and grease (moisture, protein, fiber , ash and fat), were analyzed according to A.O.AC. (2016). $\omega 3$ and $\omega 6$ content were also determined using gas chromatography according to ISO(1999).

\section{Animal studies}

Rats were fed on basal diet for two weeks as an adaption period. Rats were housed under controlled light (12: 12 light dark),

temperature were maintained at $25{ }^{\circ} \mathrm{C}$ and humidity at $60 \%$ respectively with unlimited access to food and water. Rats weights were monitored daily for one week and then twice a week for the next 6 weeks .

All efforts were made to minimize pain and distress during animal husbandry and experiments assessments .

Protocol is approved by the institutional Animal Care and Use Committee. Cairo University. 
- Beneficial effect of Flaxseed and flaxseed oil by adjusting Omega6 :O mega3 ratio

\section{High fat high cholesterol diet:}

High fat diets consists of $20 \%$ fat (10\% grease $+10 \%$ plant oil), $2 \%$ cholesterol and $1 \%$ choline chloride were mixed with diet.

40 rats were divided into 4 groups (10rats each group):positive control group (PC) , flaxseed oil group (FSO) and flaxseed group (FS),ten normal rats were fed basal diet and served as negative control group(NC) .Blood samples were collected every 3 weeks for lipid parameters monitoring (serum total cholesterol (TC), triglycerides (TG) .high density lipoprotein cholesterol (HDL) whereas low density lipoprotein cholesterol (LDL) was calculated. At the end of the experiment rats were sacrificed in a matched way so that the average length of the feeding period was the same in each group.

\section{Biochemical assay:}

Blood samples were obtained at intervals as mentioned before.

Before blood sampling, rats were fasted for 16 hours. All blood samples were collected by capillary tube from vein pleascus in the eye and centrifuged at 3000 r.p.m. to obtain serum that was stored at $-20^{\circ} \mathrm{C}$ until assayed for the determination of triglyceride, total cholesterol and high density lipoprotein (HDL).

\section{Lipid profile;}

Total cholesterol, triglycerides (TG), and high density lipoproteincholesterol (HDL-c) were determined as described by Thomas (1992), Fossati and Principle (1982), and Albers et al. (1983), respectively. Low density lipoprotein-cholesterol (LDL-c) and Very low density lipoproteincholesterol (VLDL-c) were calculated as mentioned by Lee and Nieman (1996).

\section{Rat's and organs weight:}

Initial and final rat's weight were monitored, weight gain was calculated using the following formulas:

Body weight gain $(\mathrm{BWG})(\mathrm{g})=$ Final weight - Initial weight 
After sacrifying, organs(pancreas, kidney, heart, liver, spleen and brain) were weighted.

\section{Histopathological examination:}

Tissue samples of liver and kidney were removed carefully, and fixed in neutral buffered formalin $10 \%$, dehydrated in ascending grade of alcohol, cleared and embedded in paraffin, sectioned at $5 \mu \mathrm{m}$ thickness and stained by H \& E and examined microscopically (Bancroft et al. (1996).

\section{Statistical analysis:}

Results were statistically analyzed by the L.S.D.(least significant differences ) according to Snedecor \& Cochran (1980).

\section{Results and discussion}

Table (2):Chemical composition of Flaxseed, Flaxseed oil and grease (g/100g)

\begin{tabular}{|c|c|c|c||}
\hline Items & Flaxseed & Flaxseed oil & Grease \\
\hline \hline Moisture & 7 & - & - \\
\hline Protein & 18.3 & 100 & 99.5 \\
\hline Fat & 42.2 & - & 0.5 \\
\hline Carbohydrate & 1.3 & - & \\
\hline Ash & 3.1 & - & 10.15 \\
\hline Total fiber & 27.3 & 12.70 & 0.99 \\
\hline$\omega 6$ & 5.91 & 53.30 & $10: 1$ \\
\hline$\omega 3$ & 22.81 & $1: 4.2$ & - \\
\hline $66: \omega 3$ & $1: 3.8$ & & - \\
\hline
\end{tabular}

Table (2) demonstrated the chemical composition of flaxseed, Flaxseed oil and grease of lamb, from the table it could be noticed that the moisture content of Flaxseed was found to be $7 \%$, this result was in agreement with those obtained by Gallo (2013), while protein content was $18.3 \%$ this results was slightly lower than those obtained by Gallo (2013), fat content was found to be $42.2 \%$. This result was in agreement with those obtained by Morris, et al (2003), we could noticed that Flaxseed had high content of total fiber being $(27.3 \%)$ such result was higher than those obtained by Morris, et al (2003) who found that total fiber was $22.8 \%$. with 
regard to fat content of Flaxseed oil and grease they were $100 \%$ and $99.5 \%$ respectively as grease of lamb had $0.5 \% \mathrm{~g} / 100 \mathrm{~g}$ of ash.

Regarding Omega3 ( $\omega 3)$ results showed that flaxseed oil had the highest content being $53.3 \mathrm{~g} / 100 \mathrm{~g}$ and then came flaxseed $(22.8 \%)$ while grease had the lowest amount being $0.9 \%$. with regard to Omega $6(\omega 6)$, flaxseed oil had the highest content followed by grease then Flaxseed $(12.7 \%, 10.15$ and $5.9 \mathrm{~g} / 100 \mathrm{~g})$.

With regard to $\omega 6: \omega 3$ ratio results showed that the ratio was $1: 3.8$ and $1: 4.2$ in flaxseed and flaxseed oil respectively while this ratio was 10:1 in grease.

In this respect Simopoulos \& Cleland (2003) reported that a high $\omega 6$ : $\omega 3$ ratio promotes pathogenesis of many chronic diseases like cardiovascular disease, cancer, inflammatory and autoimmune disease, rheumatoid ,arthritis, asthma, whereas increased intake of Omega -3 fatty acids (reduced Omega6/Omega3 ratio ) suppresses the effect. Secondary treatment studies have demonstrated a decline in disease progression or reversal of symptoms with decline in ratio.

Flaxseed and flaxseed oil contain high amount of Omega 3 ( $\omega 3)$ Alpha linolenic acid (ALA) and also contain Omega 6 ( $\omega 6)$ with an Omega6: Omega3 ratio of 1:3.8 for flaxseed and 1:4.2 for flaxseed oil.

The high content of $\omega 3$ in Flaxseed and Flaxseed oil can affect daily meal balance in $\omega 6$ and $\omega 3$ ratio.

The high content of $\omega 3$ as well as the balance ratio have antiinflammatory factor and have an effect on reducing and treatment the risk of many chronic diseases like atherosclerosis, cardiovascular disease, cancer and hyperlipidemia. A balance in $\omega 6: \omega 3$ intake has always been advocated for optimal health. A part from increase in $\omega 3$ intake, there is a need of reduction in absolute $\omega 6$ fatty acid intake, in this study we administrated high fat diet (10\%animal fat, $10 \%$ plant fat) and 2\% cholesterol to rats.

Effect of balance $\omega 6: \omega 3$ ratio by flaxseed oil (G3) or flaxseed(G4) on triglyceride level (mg/dl) are shown in table (3) 
Table (3): Effect of balance $\omega 6$ : $\omega 3$ ratio by flaxseed oil (G3) or 3 flaxseed(G4) on triglyceride level ( $\mathrm{mg} / \mathrm{dl})$

\begin{tabular}{||c|c|c|c|c||}
\hline \multirow{2}{*}{ Time } & \multicolumn{4}{|c|}{ Treatments } \\
\cline { 2 - 5 } & NC & PC & FSO & FS \\
\hline \hline Zero & $68.4 \pm 2.4 \mathrm{~h}$ & $199.8 \pm 5.1 \mathrm{a}$ & $197.0 \pm 3.2 \mathrm{a}$ & $195.4 \pm 3.6 \mathrm{a}$ \\
\hline 3 weeks & $69.8 \pm 2.9 \mathrm{gh}$ & $157.2 \pm 3.3 \mathrm{~b}$ & $141.0 \pm 3.4 \mathrm{c}$ & $136.2 \pm 3.6 \mathrm{~d}$ \\
\hline 6 weeks & $73.4 \pm 2.1 \mathrm{~g}$ & $115.0 \pm 2.5 \mathrm{e}$ & $85.0 \pm 2.5 \mathrm{f}$ & $81.6 \pm 2.1 \mathrm{f}$ \\
\hline
\end{tabular}

NC: Negative control

FSO :Flaxseed Oil group
PC: Positive control

FS :Flaxseed

Regarding data illustrated in table (3) mentioned the effect of treatments on hypercholesterolemic rats with flaxseed oil (G3) or flaxseed(G4) at zero time., there were a high significant increase of TG in hypercholesterolemic rats (control + ve group) as compared to healthy group control $(-\mathrm{ve})$ which were $(199.8 \pm 5.1)$ and $(68.4 \pm 2.4)(\mathrm{mg} / \mathrm{dl})$, respectively. All rats fed on flaxseed oil (G3) or flaxseed(G4) showed insignificant decreases in TG as compared to control (+ve) group. It is evident that the best treatment was of groups 4 that given flaxseed recorded $195.4 \pm 3.6 \mathrm{mg} \backslash \mathrm{dl}$.

The blood lipid profile of rats feeding high fat diet for 6 weeks revealed a great increase in TG for PC group such increase reached about 2 fold (115.0 \pm 2.5$)(\mathrm{mg} / \mathrm{dl})$ that of zero time. Regarding G3 and G4 which fed HFD supplemented with FSO and FS it could be observed that a significant decrease of TG occurred in such groups which were $85.0 \pm 2.5(\mathrm{mg} / \mathrm{dl})$ for G 3 (FSO) and $81.6 \pm 2.1$ for G4 (FS). We could noticed significant difference in triglyceride (TG) of rats in both G3, G4 and those of PC group. These results suggest that balance ratio of $\omega 6$ and $\omega 3$ with either fflaxseed or fflaxseed oil had effect in treatment $T G$ value and improving dyslipidemia.

In this respect, Mishra, (2016) found that the blood lipid profile of hypercholestremic patients before and after intake of Flaxseed oil revealed a decrease in total cholesterol (TC), triacylglycerol (TG) and change were observed only in TC and TG level with ingestion of $30 \mathrm{ml}$ of Flaxseed oil 
for a period of 3 months. He also added that there is an evidence that whole Flaxseed may lower serum cholesterol in both normal and hyperlipidemic subjects.

These results agree with Hussein, et al (2014) mentioned that treatment with Flaxseed oil to high cholesterol diet(induced hypercholesterolemia) to rats lowered serum total cholesterol, triacylglycerol, LDL.C, VLDL.C phospholipid, endothelin and homocysteine concentration in addition to increasing HDL. These result suggest that, flaxseed oil may be effective in controlling cholesterolemic status and improving dyslipidemia and has the potential in reducing cardiovascular complications due to hypercholesterolemia.

With regard to Total Cholesterol $(\mathrm{mg} / \mathrm{dl})$ in rats fed on the tested diets were illustrated in Table (4).

Table (4): Total Cholesterol (mg/dl) in rats fed on the tested diets

\begin{tabular}{||c|c|c|c|c||}
\hline \multirow{2}{*}{ Time } & \multicolumn{4}{|c||}{ Treatments } \\
\cline { 2 - 5 } & NC & PC & FSO & FS \\
\hline \hline Zero & $117.4 \pm 4.2 \mathrm{e}$ & $225.8 \pm 16.2 \mathrm{a}$ & $225.8 \pm 16.2 \mathrm{a}$ & $225.8 \pm 16.2 \mathrm{a}$ \\
\hline 3 weeks & $118.8 \pm 3.9 \mathrm{e}$ & $210.0 \pm 17.4 \mathrm{~b}$ & $173.0 \pm 8.7 \mathrm{c}$ & $179.8 \pm 7.9 \mathrm{c}$ \\
\hline 6 weeks & $121.8 \pm 2.4 \mathrm{e}$ & $202.4 \pm 4.0 \mathrm{~b}$ & $120.4 \pm 3.0 \mathrm{e}$ & $134.2 \pm 1.9 \mathrm{~d}$ \\
\hline
\end{tabular}

NC: Negative control

PC: Positive control

FSO :Flaxseed Oil group

FS :Flaxseed

Data recorded in table (4) show the effect of Flaxseed Oil \& Flaxseed on total cholesterol ((TC) of hypercholesterolemic Rate. Control (+ve) groups showed significant increase in total cholesterol as compared to healthy rats which were $225.8 \pm 16.2 \mathrm{mg} / \mathrm{dl}$ and $117.40 \pm 2.00 \mathrm{mg} / \mathrm{dl}$, respectively. Rats of Flaxseed Oil \& Flaxseed treatments reversed the change occurring in control (+ve) rats leading to decrease TC show significant high decrease and Maximum decrease of total cholesterol recorded for group 3 which fed on Flaxseed Oil.

Our results are in agreement with those obtained by Aly-Aldin et al, (2015) who found that positive control rats had 
higher triglyceride and total lipids values than negative control rats and rats fed different replacement levels of flaxseed oil.

Effect of balance $\omega 6: \omega 3$ ratio by Flaxseed and Flaxseed oil on serum HDL on rats fed HFD are shown in table (5)

Table (5): Effect of balance $\omega 6: \omega 3$ ratio by Flaxseed and Flaxseed oil on serum HDL on rats fed HFD

\begin{tabular}{|c|c|c|c|c||}
\hline \multirow{2}{*}{ Time } & \multicolumn{4}{|c|}{ Treatments } \\
\cline { 2 - 5 } & NC & PC & FSO & FS \\
\hline \hline Zero & $27.8 \pm 2.3 \mathrm{e}$ & $34.8 \pm 2.5 \mathrm{~b}$ & $26.4 \pm 1.1 \mathrm{e}$ & $27.6 \pm 1.1 \mathrm{e}$ \\
\hline 3 weeks & $30.4 \pm 3.0 \mathrm{~d}$ & $32.2 \pm 2.3 \mathrm{~cd}$ & $30.8 \pm 0.8 \mathrm{~d}$ & $32.8 \pm 1.9 \mathrm{c}$ \\
\hline 6 weeks & $35.0 \pm 2.5 \mathrm{~b}$ & $30.4 \pm 1.1 \mathrm{~d}$ & $40.0 \pm 1.0 \mathrm{a}$ & $38.4 \pm 1.1 \mathrm{a}$ \\
\hline
\end{tabular}

HFD: high fat high cholesterol diet

NC: Negative control

FSO :Flaxseed Oil group
HDL: high density lipoprotein

PC: Positive control

FS : Flaxseed

The obtained results in table (5) revealed a significant decrease in serum HDL-c on rats fed on hypercholesterolemic diet control (+ve group) - All rats of hypercholesterolemia, and fed on Flaxseed Oil group \& Flaxseed showed a significant increase in HDL-c from zero time till 6 weeks as compared to control $(+\mathrm{ve})$ positive group

In this respect, Aly-Aldin et al (2015) mentioned that Flaxseed oil at different replacement levels resulted in a significant $(\mathrm{P} \leq 0.05)$ increased in HDL values as compared with positive control rats. These results similar to Khalesi et al (2011) who found that there was a significant increase in blood HDL- C in rats after treatment with $20 \%$ raw flaxseed group (3.6\% increased) and they found also that in 30\% flaxseed group both raw and heated flaxseed group also showed a significant increase in HDL $4.81 \%$ and $6 \%$ respectively when compared to control group. Also, Our results are in agreement of those obtained by Mohamed \& Afifi (2011) who found that normal rats fed on flaxseed oil have higher significant HDL than control group. 
Effect of FS and FSO on serum LDL of rats fed HFD (mg/dl) are shown in table (6)

Table (6): Effect of FS and FSO on serum LDL of rats fed HFD (mg/dl)

\begin{tabular}{||c|c|c|c|c||}
\hline \multirow{2}{*}{ Time } & \multicolumn{4}{|c||}{ Treatments } \\
\cline { 2 - 5 } & NC & PC & FSO & FS \\
\hline \hline Zero & $131.6 \pm 4.2 \mathrm{f}$ & $218.4 \pm 14.5 \mathrm{a}$ & $212.8 \pm 15.4 \mathrm{a}$ & $214.2 \pm 15.7 \mathrm{a}$ \\
\hline 3 weeks & $135.0 \pm 4.8 \mathrm{ef}$ & $212.8 \pm 18.1 \mathrm{a}$ & $175.6 \pm 9.6 \mathrm{c}$ & $185.4 \pm 9.2 \mathrm{~b}$ \\
\hline 6 weeks & $142.0 \pm 3.2 \mathrm{e}$ & $209.6 \pm 4.3 \mathrm{a}$ & $143.4 \pm 4.0 \mathrm{e}$ & $156.8 \pm 1.3 \mathrm{~d}$ \\
\hline
\end{tabular}

HFD: high fat high cholesterol diet LDL: low density lipoprotein

NC: Negative control

PC: Positive control

FSO :Flaxseed Oil group

FS :Flaxseed

The data detected in Table (6) represent the effect of FSO and FS supplementation on serum LDL in rats fed on HFD after 3 and 6 weeks.

From the result it could be noticed that feeding rats on HFD (PC) for 6 weeks, resulting in significant increase in LDL-c as compared to normal healthy rats (NC) at zero time. Meanwhile, Co-administration of FSO and FS with the high fat diet for the same period led to significant decrease in LDL level after 6 weeks. On the other hand LDL at NC control showed a little bit of increase in LDL after 6 weeks. These results are in agreement with that's obtained by Mishra (2016) who found that whole Flaxseed powder had profound effect on lowering the blood lipid profile as whole flaxseed powder significantly reduces LDL and TC by $7.66 \%$ and $9.7 \%$ respectively.

Flaxseeds have received attention for their potential role in treatment lipid disorders. However many people are still unaware of the potential health benefits of Flaxseed and the importance of adjusting the ratio between $\omega^{6} 6: \omega_{3}$.

These results are in agreement with those obtained by Ali et al (2017) who found that Feeding rats on high cholesterol diet for 12 weeks, resulting in a significant $(\mathrm{P}<0.001)$ increase in serum TG, T.C, LDL and VLDL levels by 3.2, 1.9, 3.0 and 3.2- fold, respectively above the normal 
levels, a combined with significant $(\mathrm{P}<0.001)$ decrease in HDL by $24.9 \%$ as compared to control groups. Meanwhile Co-administration of Flaxseed oil at low dose with HCD for the same period had significantly decreased serum TG, TC, LDL and vLDL levels by $31.0 \%, 15.6 \%, 18.0 \%$ and $31.0 \%$ respectively and a combined with a significant increase in HDL by $3.8 \%$ versus HCD fed group. Furthermore, Co- administration of flaxseed oil at double dose cause significantly decreased serum TG, TC, LDL- C and vLDL levels by $57.5 \%, 37.3 \%, 47.6 \%$ and $57.5 \%$ respectively and a combined with a significant increase in HDL by $15.7 \%$ versus HCD fed group .

Effect of balanced $\omega: \omega_{3}$ ratio with FS and FSO on weight gain after 6 weeks are shown in table (7).

Table (7): Effect of balanced $\omega 6: \omega_{3}$ ratio with FS and FSO on weight gain after 6 weeks.

\begin{tabular}{|c|c|c|c||}
\hline Treatments & Initial weight & final weight & \% weight gain \\
\hline \hline NC & $176.2 \pm 47.6 \mathrm{a}$ & $205.2 \pm 46.0 \mathrm{a}$ & $29 \pm 13.5 \mathrm{~b}$ \\
\hline PC & $206.4 \pm 32.0 \mathrm{a}$ & $240.0 \pm 44.6 \mathrm{a}$ & $33.6 \pm 7.1 \mathrm{a}$ \\
\hline FSO & $219.8 \pm 40.4 \mathrm{a}$ & $249.2 \pm 41.9 \mathrm{a}$ & $29.4 \pm 19.4 \mathrm{~b}$ \\
\hline FS & $232.6 \pm 14.2 \mathrm{a}$ & $251.0 \pm 13.9 \mathrm{a}$ & $18.4 \pm 2.0 \mathrm{c}$ \\
\hline
\end{tabular}

NC: Negative control

FSO :Flaxseed Oil group
PC: Positive control

FS :Flaxseed

Result in table (7) showed the initial, final and body weight gain for both negative control fed basal diet(NC) and positive control fed high fat high cholesterol diet (PC) and treated groups fed high fat high cholesterol diet while have adjusting ratio of Omega 6:Omega3 by adding either flaxseed oil (FSO) or flaxseed(FS) .

From the results we could noticed that PC group recorded the highest percentage of gain in body weight $(33.6 \%)$ and there was a significant difference between such group and the other groups. On the other hand no significant differences were noticed between the group of rats fed basal diet (NC) and each of FSO and FS groups which orally administrated 
with adjusting ratio of $\omega 6: \omega 3$ by Flaxseed oil and Flaxseed which recorded weight gain of $29.4 \%$ and $18.4 \%$ respectively ,such groups had gain in body weight approxomilty similar to NC group although they were fed high fat diet.

These results agree well with those reported by Aly-Aldin et al (2015) who showed that hypercholesterolemic rats fed standard diet (positive control rats) had higher $(\mathrm{P} \leq 0.05)$ body weight gain than normal rats fed standard diet (negative control rats) and hypercholesterolemic rats fed different replacement levels of flaxseed oil diets.

In this respect Mohamed and Afifi (2011) in their study about the effect of FSO on plasma lipid profiles as well as body and organs weight found that there is a significant decrease for body weight gain in group fed Flaxseed in comparison with control group.

Effect of adjusting $\omega 6: \omega 3$ ratio flaxseed and flaxseed oil on organs weight of rat fed high fat diet are shown in table (8)

Table (8):Effect of adjusting $\omega 6: \omega 3$ ratio flaxseed and flaxseed oil on organs weight of rat fed high fat diet

\begin{tabular}{|c|c|c|c|c|c|c||}
\hline Treatments & liver & relative & spleen & relative & pancreas & relative \\
\hline \hline NC & $4.7 \pm 0.76$ & $2.4 \pm 0.43$ & $0.8 \pm 0.08$ & $0.4 \pm 0.07$ & $0.3 \pm 0.04$ & $0.2 \pm 0.04$ \\
\hline PC & $6.5 \pm 0.51$ & $2.7 \pm 0.30$ & $0.9 \pm 0.05$ & $0.4 \pm 0.05$ & $0.2 \pm 0.04$ & $0.1 \pm 0.01$ \\
\hline FSO & $5.5 \pm 0.40$ & $2.2 \pm 0.28$ & $0.7 \pm 0.18$ & $0.3 \pm 0.03$ & $0.3 \pm 0.03$ & $0.1 \pm 0.02$ \\
\hline FS & $5.8 \pm 0.14$ & $2.3 \pm 0.12$ & $0.8 \pm 0.11$ & $0.3 \pm 0.03$ & $0.3 \pm 0.03$ & $0.1 \pm 0.01$ \\
\hline \hline
\end{tabular}

NC: Negative control

FSO :Flaxseed Oil group
PC: Positive control

FS :Flaxseed 


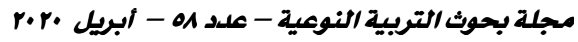

F0llow Table (8):Effect of adjusting $\omega 6: \omega 3$ ratio flaxseed and flaxseed oil on organs weight of rat fed high fat diet

\begin{tabular}{|c|c|c|c|c|c|c||}
\hline Treatments & kidney & relative & heart & relative & brain & relative \\
\hline \hline NC & $1.4 \pm 0.20$ & $0.7 \pm 0.31$ & $0.7 \pm 0.10$ & $0.4 \pm 0.05$ & $1.4 \pm 0.12$ & $0.7 \pm 0.12$ \\
\hline PC & $1.6 \pm 0.18$ & $0.7 \pm 0.05$ & $0.7 \pm 0.10$ & $0.3 \pm 0.04$ & $1.2 \pm 0.04$ & $0.5 \pm 0.08$ \\
\hline FSO & $1.5 \pm 0.15$ & $0.6 \pm 0.13$ & $0.7 \pm 0.07$ & $0.3 \pm 0.03$ & $1.3 \pm 0.05$ & $0.6 \pm 0.09$ \\
\hline FS & $1.5 \pm 0.22$ & $0.6 \pm 0.07$ & $0.7 \pm 0.04$ & $0.3 \pm 0.02$ & $1.4 \pm 0.03$ & $0.6 \pm 0.02$ \\
\hline
\end{tabular}

NC: Negative control

PC: Positive control

FSO :Flaxseed Oil group

FS :Flaxseed

The obtained data in table (8) illustrated that there was a decrease in liver weight in $\mathrm{G}_{3}$ and $\mathrm{G}_{4}$ (FSO and FS) compared with PC. The decrease in liver weight may be due to enhanced of catabolic processes such as glycogenolysis, Lipolysis and proteolysis, these results are in agreement with those obtained by Yadav et al., (2004). Results in the same table showed that there were no significant differences between NC and each of FS and FSO in liver weight, on the other hand there was a significant difference between such groups and PC.

In the same table there were no significant differences among relative weight of each of pancreas and heart in all groups.

However, there were no significant differences among the mean values of relative weights for spleen and kidney in FSO compared with the negative control.

Regarding brain relative weight of FSO and FS, Results showed no significant difference between such groups, while a significant difference was found among FS and each of the negative and positive control.

\section{Histopathology}

Liver of control rats showed normal hepatic parenchyma with normally arranged hepatic cords (fig. 1a) and normal kidney tissue (fig. 2a). Whereas Liver of control +ve group showed diffuse vacuolar degeneration 
of hepatocytes (fig. 1b) and sinusoidal leukocytosis. Portal area showed marked congestion of portal blood vessels associated with extensive portal edema, hyperplasia of biliary epithelium and marked thickening of the arteriolar lumen (fig. 1c).

Kidney showed variable histopathological alterations varying from glomerular congestion ( fig. 2b), mesangial expansion with vacuolar degeneration of the surrounding renal tubules ( fig. 2c ) and focal glomerulosclerosis (fig. 2d). Renal tubules revealed granular degeneration of their epithelial lining with nuclear pyknosis and intracytoplasmic aggregation of hyaline droplets (fig. 2e), tubular dilatation and intraluminal aggregation of protein cast (fig. 2f) as well as congestion of intertubular blood capillaries and mild focal interstitial mononuclear cell infiltration associated with perivascular edema.

Group 5 showed alleviated histopathological alterations compared to the control positive group. Liver showed mild vacuolar degeneration of hepatocytes with mild sinusoidal leukocytosis (fig. 1d) and mild portal edema (fig. 1e). Kideney revealed necrosis of individual cells lining renal tubules (fig. $2 \mathrm{~g}$ ).

Group 10 showed less improved histopathological alterations compared to group 5 as liver showed focal hepatic steatosis (fig. 1f) and sinusoidal leukocytosis and extensive portal edema. Kidney showed mild vacuolar degeneration of some epithelial cells lining renal tubules associated with tubular dilatation (fig. $2 \mathrm{~h}$ ). . 


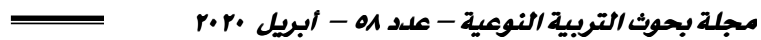

Fig (1):Liver of the control and treated groups
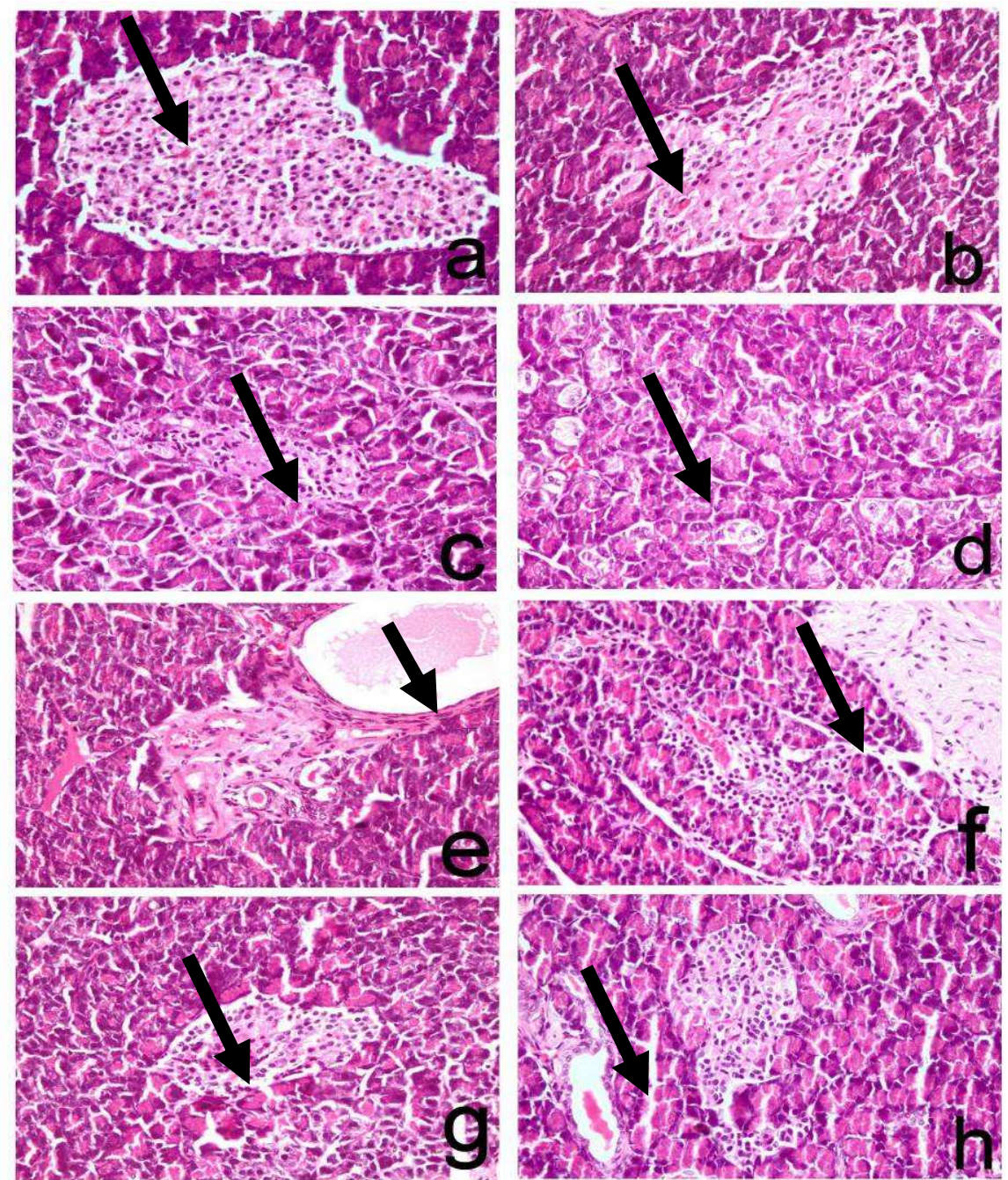
- Beneficial effect of Flaxseed and flaxseed oil by adjusting Omega6:O mega3 ratio

Fig (2):kidney of the control and treated groups
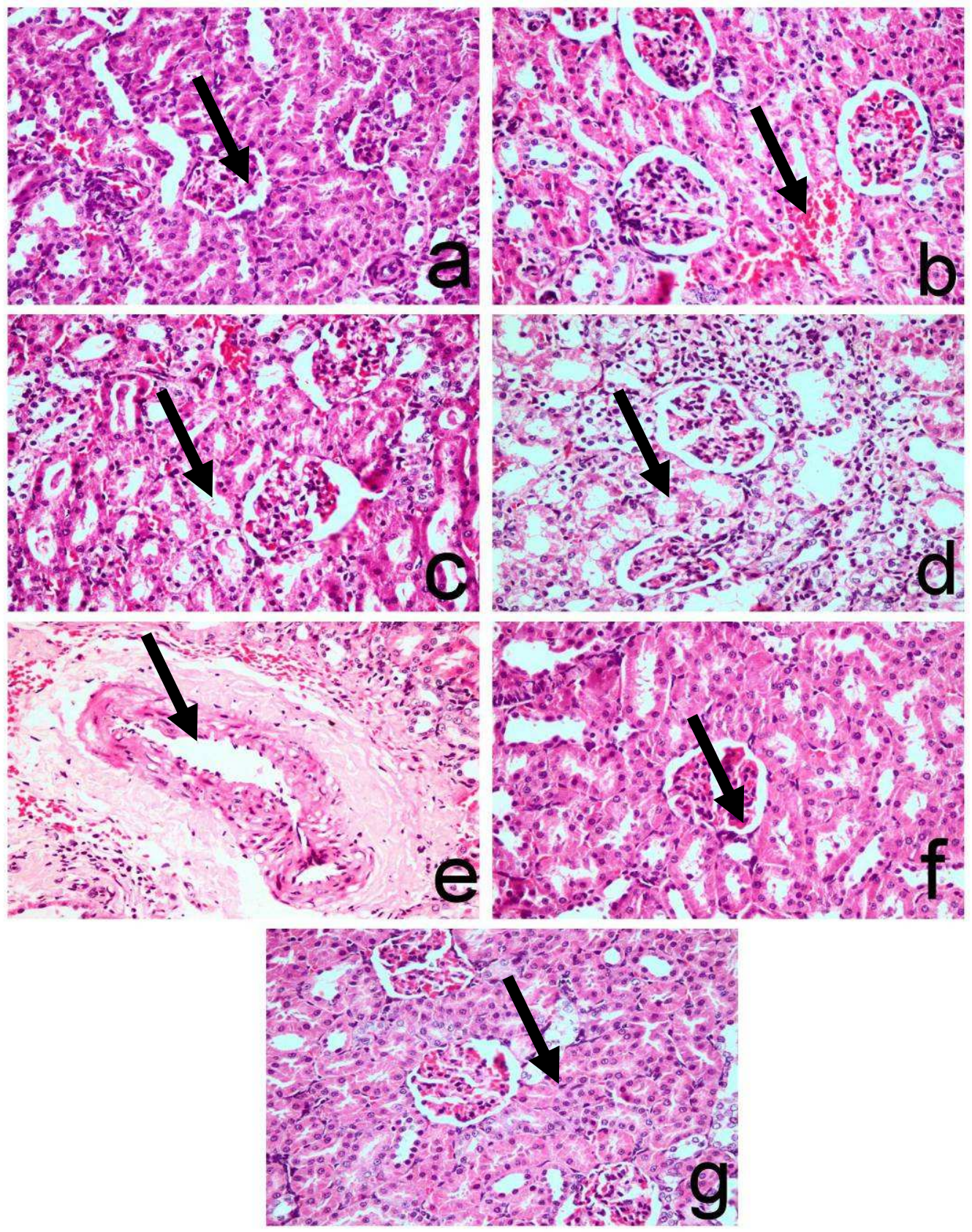


\section{References}

- Ali, Z. Y. El-Yamany, M. Tawfeeq, M. and Ahmed, H.H. (2017): Flaxseed oil effectively reduces the risk of development of atherosclerosis in rats fed on high cholesterol diet. Annual Research \& Review in Biology 14 (3): 1- 17.

- Aly-Aldin, M. M., Mansour, E. H., Rahma, E. H., El, A. E. E. B. A., ElBedawey, F. A., \& El-Habashy, M. M. (2015). Protective role of flaxseed oil on hypercholesterolemic rats. Biolife, 3, 794-801.

- Albers, N., Benderson, V., \&Warnick, G. (1983).Enzymatic determination of high density lipoprotein cholesterol: Selected Methods. Clin.Chem, 10, 91-99

- A.O. A.C. (2016): Association of Analysis Chemists Official methods of analysis of the association of analysis Chemists 18 th edition, Washington. D.C.U.S.A

- Bancroft, J. D., Stevens, A., \& Turner, D. R. (1996). Theory and Practice of Histological Techniques, 4th edn (New York, Churchill Livingstone).

- Dupasquier, C. M., Weber, A. M., Ander, B. P., Rampersad, P., Steigerwald, S., Wigle, J. T., ... \& Lukas, A. (2006). The effects of dietary flaxseed on vascular contractile function and atherosclerosis during prolonged hypercholesterolemia in rabbits. American Journal of Physiology-Heart and Circulatory Physiology.

- Fossati, P. and Principe, L. (1982): Determination of triglycerides. Clinical Chemistry, 28: 2077-2078.

- Gallo. M. (2013): Preparing and Evaluating some meals high in Essential faulty acids using flaxseed. Thesis Faculty of Agriculture Alexandria University.

- Gupta, R ., Lakshmy, R., Abraham, R., Reddy, K., Jeemon, P. \&Prabhakaran, D. (2013): Serum Omega- 6/ Omega- 3 Ratio and Risk Markers for Cardiovascular Disease in an Industrial population of Delhi Scientific Research, Food Nutrition \& Science, (4): 94- 97.

- Hussein, S.A., El-senosi, Y.A. Ragab. M.R. and Hammad, M.F. (2014): Beneficial effect of Flaxseed oil on lipid metabolism in high cholesterol diet fed rats. Benha Veterinary Medical Journal (BVMJ), 27 (2): 290- 301.

- ISO (1999): Methylation of Fatty Acids scholar

- Khalest, S, Januluddin, R. \& Ismail, A. (2011). Effect of Raw and Heated Flaxseed (Linum lisitatissimuml). On Blood lipid profiles in Rats. International Journal of Applied Science and Technology, Vol. 1 No. 4 July. 
- Molena-Fernandes, C. A., Schimidt, G., Neto-Oliveira, E. R., Bersani- Amado, C. A., \& Cuman, R. K. N. (2010). Avaliação dos efeitos da suplementação com farinha de linhaça (Linumusitatissimum L.) marrom e dourada sobre o perfil lipídico e a evolução ponderal em ratos Wistar. Revista Brasileira de Plantas Medicinais, 12(2), 201-207

- Moss, J. W., \& Ramji, D. P. (2016). Nutraceutical therapies for atherosclerosis. Nature Reviews Cardiology, 13(9), 513.

- Mishra, N. (2016): Effect of whole flaxseed and flaxseed oil in CVD patient, Health Sciences: An International Journal, 6 (1): 1-7.

- Morris, D. H., Vaisey-Genser, M., Thompson, L. U., \& Cunnane, S. C. (2003). Availability and labeling of flaxseed food products and supplements. Flaxseed in human nutrition, (Ed. 2), 404-422.

- Mohamed, M.S. and Afifi, A.A. (2011): Effect of some polyunsaturated fatty acids rich-oils on plasma lipid profiles using normal rats. J. Agric- Chem. and Biotechn. Mansoura Uni. 2 (2): 49-59.

- Newairy, A. S. A., \& National Institutes' Health(2012):U.S department of health and human services Abdou, H. M. (2009). Protective role of flax lignans against lead acetate induced oxidative damage and hyperlipidemia in rats. Food and Chemical Toxicology, 47(4), 813-818.

Herbs at a glance . www.ncbi.n/m.nih.gov/pubmed

- Lee, R. and Nieman, D. (1996): Nutrition Assessment. 2nd Ed. Mosby, Missouri, USA. 591 - 594.

- Prasad, K. (2005). Hypocholesterolemic and antiatherosclerotic effect of flax lignan complex isolated from flaxseed. Atherosclerosis, 179(2), 269-275.

- Ruel. I.;Brisson, D .; Aljenedil, S .; Awan, Z.; Baass, A .; Bélanger, A.; Bergeron, J., Bewick. D.; Brophy, J.M.; Brunham, L.R.; Couture, P.; , Dufour, R.; Francis, G.A.; Frohlich,J.; Gagné, C.; Gaudet,D.; Grégoire, J.C.; Mancini, G.B..;McCrindle, B.W.; Pang, J.; Raggi, P.; Tu, J.V.;Watts, G.F. and Genest, J.; (2018): Simplified CanadianDefinition forFamilial Hypercholesterolemia Can J Cardiol. .05.015.

- Simopoulos, A. (2016): An increase in the Omega- 6/ Omega- 3 Fatty acid ratio increase the risk of obesity. Nutrients: 8 (128): dot: 10. 3390/ nu 8030128. 
- Sammour, R. H. (1999). Proteins of linseed (Linum usitatissimum L.), extraction and characterization by electrophoresis. Botanical Bulletin of Academia Sinica, 40.

- Simopoulos, A. P., \& Cleland, L. G. (2003). Subject Index. In Omega-6/Omega3 Essential Fatty Acid Ratio: The Scientific Evidence (Vol. 92, pp. 170-174). Karger Publishers.

- Snedecor , G.W and Cochran, W.G. (1980).Statistical methods. Oxford and J.B.H publishing Con 7 th edition. pp1-172.

- Thomas, L. (1992): Labor and Diagnose. 4th Edition, Die Medizinische Verlagsgesellschachft, Margurg. advances in bioscience and biotechnology, Vol.6 No.4.

- Yadav, J. S., Wholey, M. H., Kuntz, R. E., Fayad, P., Katzen, B. T., Mishkel, G. J. \& Popma, J. J. (2004). Protected carotid-artery stenting versus endarterectomy in high-risk patients. New England Journal of Medicine, 351(15), 1493-1501.

- WHO. World Health Organization Fact Sheet 317; 2015.Available:http://www.who.int/mediacentre/factsheets/fs317/en/

- Whelan, J., \& Rust, C. (2006). Innovative dietary sources of n-3 fatty acids. Annu. Rev. Nutr., 26, 75- 
= Beneficial effect of Flaxseed and flaxseed oil by adjusting Omega6 :O mega3 ratio

التأثير الفيد لريت الكتان وبذور الكتان عن طريق ضبط نسبة أوهيجا 1 أوهيغا ب على التمثيل الغذائي للدهون في الفئران التي تغذى على نسبة عالية هن الكوليسترول

* مشامدحتمراد

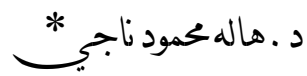

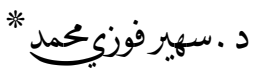

المفص العربي

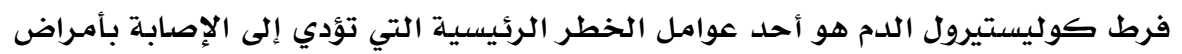

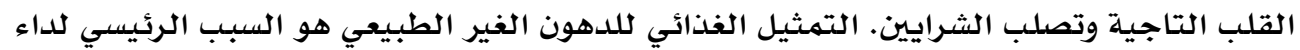

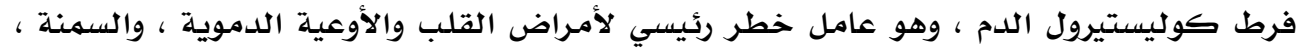

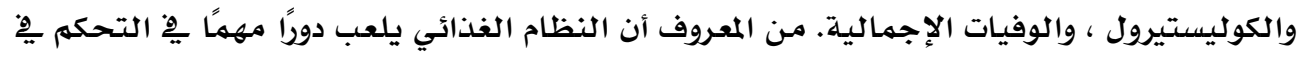

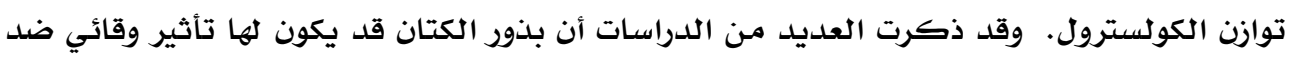

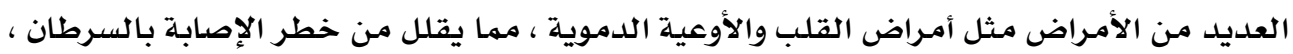

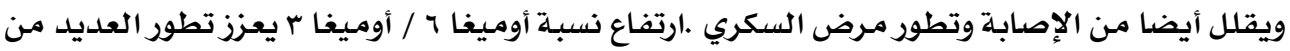

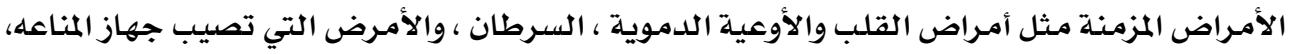

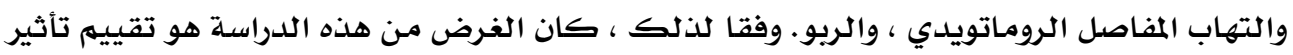

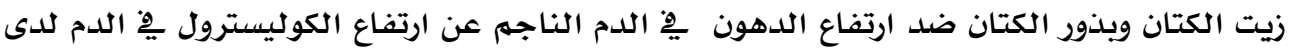

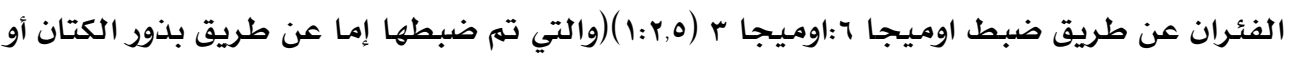

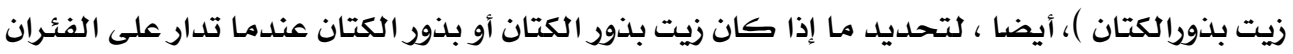

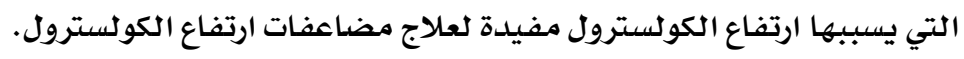

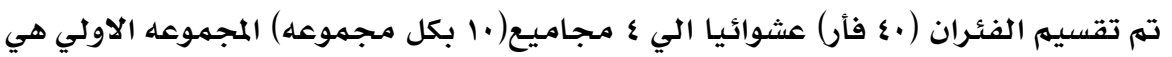

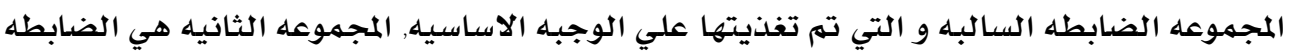

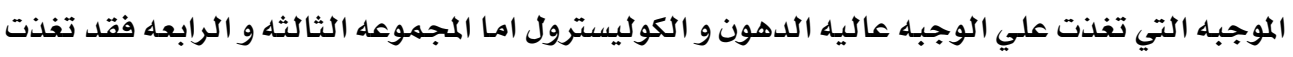

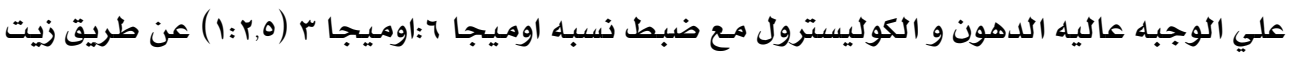

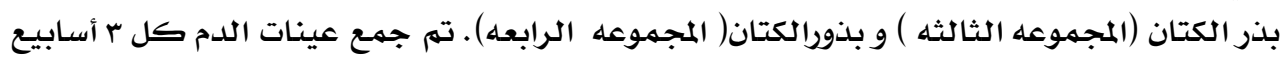

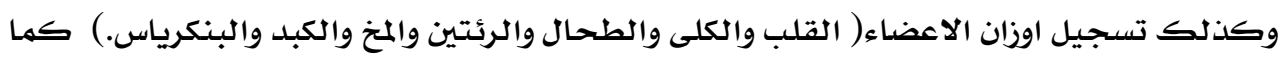

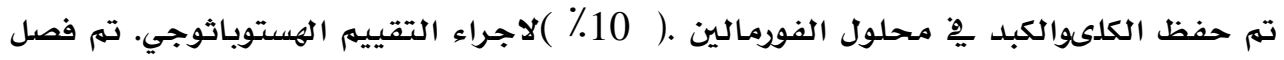

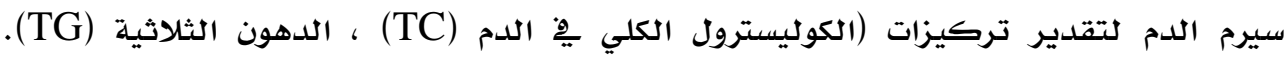

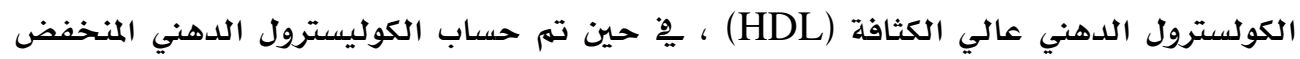
الكثافة (LDL).

و قد اثبتت النتائج انخفاض معنوي لكل من كوليستيرول الدم و الدهون الثلاثيه و

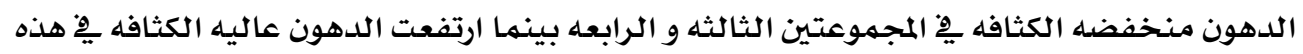


مجلة بحوث التربية النوعية - علدد

المجاميع .كمابينت النتائج ان ضبط النسبه ِِّ الوجبه ادي لانخفاض اوزان الفئران مقارنه

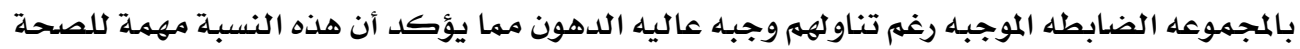

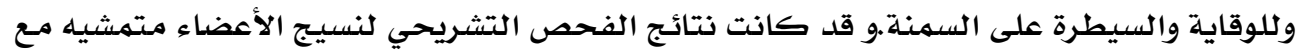

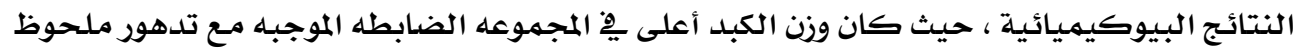

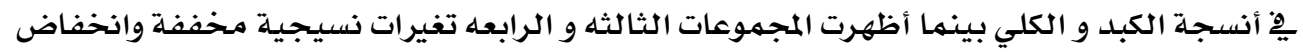

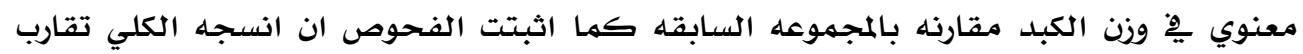

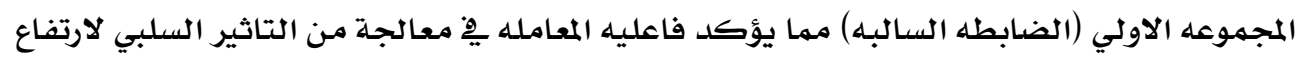

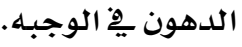

الكلمات المفتاحيه: نسبه اوميجا ب:اوميجا r r, دهون الدم ,خلايا الكبد,وجبات عاليه الدهون ,

أوزان الفئران,بذورالكتان زيت بذور الكميه: نسبه اوميجان. 